\title{
Global Solar Radiation Characteristics at Calabar and Port Harcourt Cities in Nigeria
}

\author{
Solomon Okechukwu Amadi ${ }^{a^{*}}$, Timothy Dike ${ }^{\mathrm{a}}$, and Samuel Chukwujindu Nwokolo ${ }^{\mathrm{b}}$ \\ ${ }^{a}$ Dept of Physics, Geology \& Geophysics, Alex Ekwueme Federal University, Ndufu-Alike, Nigeria \\ ${ }^{b}$ Dept of Physics, Faculty of Physical Sciences, University of Calabar, Nigeria
}

Received February 22, 2020; Accepted March 27, 2022; Published April 7, 2020

\begin{abstract}
This study analyzed the inter-annual variability in solar radiation at Port Harcourt and Calabar, aiming at improving knowledge of solar resources. For the investigation, monthly mean global solar radiation data for fifteen years $(2000$ - 2014) was collected from Nigerian Meteorological Agency (NIMET), and the monthly mean extraterrestrial solar radiation was determined using globally recognized standard relation. The clearness index parameter was employed for characterizing the spatial variability of solar radiation for Calabar and Port Harcourt. The statistics of the monthly mean solar radiation deviations of Port Harcourt and Calabar was tested using the Kolmogorov-Smirnov method. The test results showed that they are normally distributed random variables. Furthermore, the analysis of sequential properties showed that the coefficients of the auto-correlation with lag 1 are significant for both stations. The autocorrelation coefficients with lag 1 , though usually not significant, are negative for both stations. The auto regression lag 1 (AR-1) is the recommended procedure (model equation) for generating monthly solar radiation synthetic time series, with auto-correlation coefficients varying from 0.30 to 0.47 for both stations in the South-South of Nigeria.
\end{abstract}

Keywords: Global solar radiation; Clearness index; Extraterrestrial solar radiation; Calabar; Nigeria

\section{Introduction}

A wide range of solar energy applications, including modeling, design of solar crop dryers, and photovoltaic system sizing, requires a huge amount of knowledge of global solar radiation. The daily solar radiation intensity is normally among the variables collected by weather stations. The important role played by knowledge sharing in the subject of solar radiation and its subsequent exploitation has necessitated the need to develop ways of predicting the incident solar radiation in the interest of the regions of the globe like tropical Africa, where routine measurements are lacking in spite of the huge availability of solar energy in the region [1]. As the fossil fuel reserves suffer severe depletion, it becomes imperative that alternative energy resources should be explored and utilized with high conversion efficiency to help bridge the wide gap between energy supply and energy demand [2]. For sub-Saharan African countries such as Nigeria, the economic and efficient utilization of solar energy has become inevitable because of the abundance and reliability of solar energy resource. Augustine and Nnabuchi [3] estimated that Nigeria has approximately 3,000 hours of annual sunshine. Offiong [4] stated that the mean daily solar radiation received in Nigeria is up to $20 \mathrm{MJ} / \mathrm{m}^{2} /$ day. This, however, 
depends on the location and the time of the year. Despite this huge amount of solar energy, Nigeria with a rural population of over 97,000 inhabitants [5], still has her population suffering deprivation from conventional energy due to poor infrastructural facilities and subsequent unreliability in energy supply.

Solar energy is among the most important alternative energy resources with excellent potentials for utilization in both rural and urban communities. Having vast knowledge of the distribution of solar energy at a geographical location is significant for the creation and advancement of new solar energy devices with improved efficiency [6]. Data on solar radiation is a basic requirement for conducting feasibility studies with respect to solar energy systems. Augustine and Nnabuchi [3] opined that the knowledge of solar energy acquired over a long period ought to be applicable not only to the site where the radiation data was collected, but also to other locations with similar climates.

Nigeria is located between Latitude $4^{\circ} \mathrm{N}$ and $14^{\circ} \mathrm{N}$. This vantage position enables the country to receive a vast amount of solar energy throughout the year. Solar radiation data can be accessed in a variety of forms depending on choice and application. Several scholars $[1,2,4,6]$ have emphasized the importance of solar radiation data in the design and operation of efficient solar energy devices which are anchored on accurate and detailed information of solar radiation climatology. The diurnal and seasonal patterns of both the hourly/daily clearness and the cloudiness indices were clearly shown in the datasets. Okogbue et al [7] investigated the optical sky conditions in some selected locations in the major ecological zones of Nigeria using monthly global solar irradiance data for an interval not less than 20 years. Many empirical studies on the portioning of solar irradiance have been presented for various regions of the world [8].

Solar irradiance is defined as the power per unit area $\left(\mathrm{W} / \mathrm{m}^{2}\right)$ received from the sun in the form of electromagnetic radiation within the range of wavelength that the measuring instrument can detect. When the solar irradiance is integrated over time, it is referred to as solar irradiation, insolation, or solar exposure. Nevertheless, for practical purposes, it is apt to often use insolation and irradiance interchangeably. Irradiance may be measured on top of the atmosphere or at the earth's surface after atmospheric attenuation effects of absorption, reflection and scattering. Irradiance measured on top of the atmosphere depends on such factors as distance from the sun, the solar cycle, and changes in cross-cycle. In addition, irradiance on the earth's surface is affected by the tilt of the measuring surface, the solar altitude, and the conditions of the atmosphere. Solar radiation is radiant energy which the sun emits, essentially electromagnetic energy. Almost half of the radiation is contained in the visible wave band of the electromagnetic spectrum (www.sciencedaily.com/terms/solar_radiation htm). The other half mostly lies in the near-infrared band, while some lie in the ultraviolet region of the spectrum. The aim of the study is to characterize the global solar radiation at Port Harcourt and Calabar in South-South Nigeria using 15 years' data (2000-2014).

\section{Study Area}

Port Harcourt and Calabar have a tropical climate with wet and dry seasons. Two distinct wet seasons are observed: the more intense season is observed from April to July whereas a less intense one occurs from September to November. At the peak of the wet season, the meteorological condition at the stations is wet about half the time. Port Harcourt and Calabar experience a dry season (when rain falls less than two days in a 
month) in August, as well as from December to March. This second part of dry season is accompanied by Harmattan winds which originate from the Sahara Desert and have their peak from December to early February. Port Harcourt and Calabar have a fairly small temperature range, generally between $33^{\circ} \mathrm{C}$ and $21^{\circ} \mathrm{C}$. The hottest month is March, when the mean diurnal temperatures reach about $29^{\circ} \mathrm{C}$. July is the coldest month with a mean temperature of about $25^{\circ} \mathrm{C}$ [9]. The geographical information of the study area is presented in Table 1, while the map showing the distance between the locations under study (Port Harcourt and Calabar) is shown in Fig. 1.

Table 1. Meteorological stations

\begin{tabular}{cccc}
\hline Station name & Latitude & Longitude & Elevation. \\
\hline Calabar & $4.71^{\prime} \mathrm{N}$ & $8.55^{\prime} \mathrm{E}$ & $62.3 \mathrm{~m}$ \\
Port Harcourt & $4.40^{\prime} \mathrm{N}$ & $7.17^{\prime} \mathrm{E}$ & $19.55 \mathrm{~m}$ \\
\hline
\end{tabular}

\section{Methodology}

\subsection{Data}

The monthly mean daily ground - measured global solar radiation data used for this study (Port Harcourt and Calabar) was obtained from the Nigeria Meteorological Agency, Oshodi Lagos [10]. The data accessed covered a period of fifteen years (20002014) for Port Harcourt and Calabar. The monthly mean daily extraterrestrial solar radiation $\left(H_{O}\right)$ is the solar radiation received by horizontal surface during a day at the top of the atmosphere, calculated using the procedure for monthly mean extraterrestrial solar radiation shown in Table 2 and expressed theoretically as:

$$
H_{O}=\frac{24}{\pi} I_{S C}\left(1+0.033 \cos \frac{360 n}{365}\right) \times\left(\cos \phi \cos \delta \sin \omega_{S}+\frac{2 \pi \omega_{S}}{360} \sin \phi \sin \delta\right)
$$

The mean sunrise hour angle $\left(\omega_{s}\right)$ can be evaluated as:

$$
\begin{aligned}
& \omega_{s}=\cos ^{-1}[\tan \delta \tan \phi] \\
& \delta=23.45 \sin \left[\frac{360(n+284)}{365}\right]
\end{aligned}
$$

where $\phi$ represents the latitude, $\delta$ is the solar declination and $\mathrm{n}$ is the number of days of the year beginning from first January. ISC is the solar constant and other symbols retain their meanings in the usual notation. 


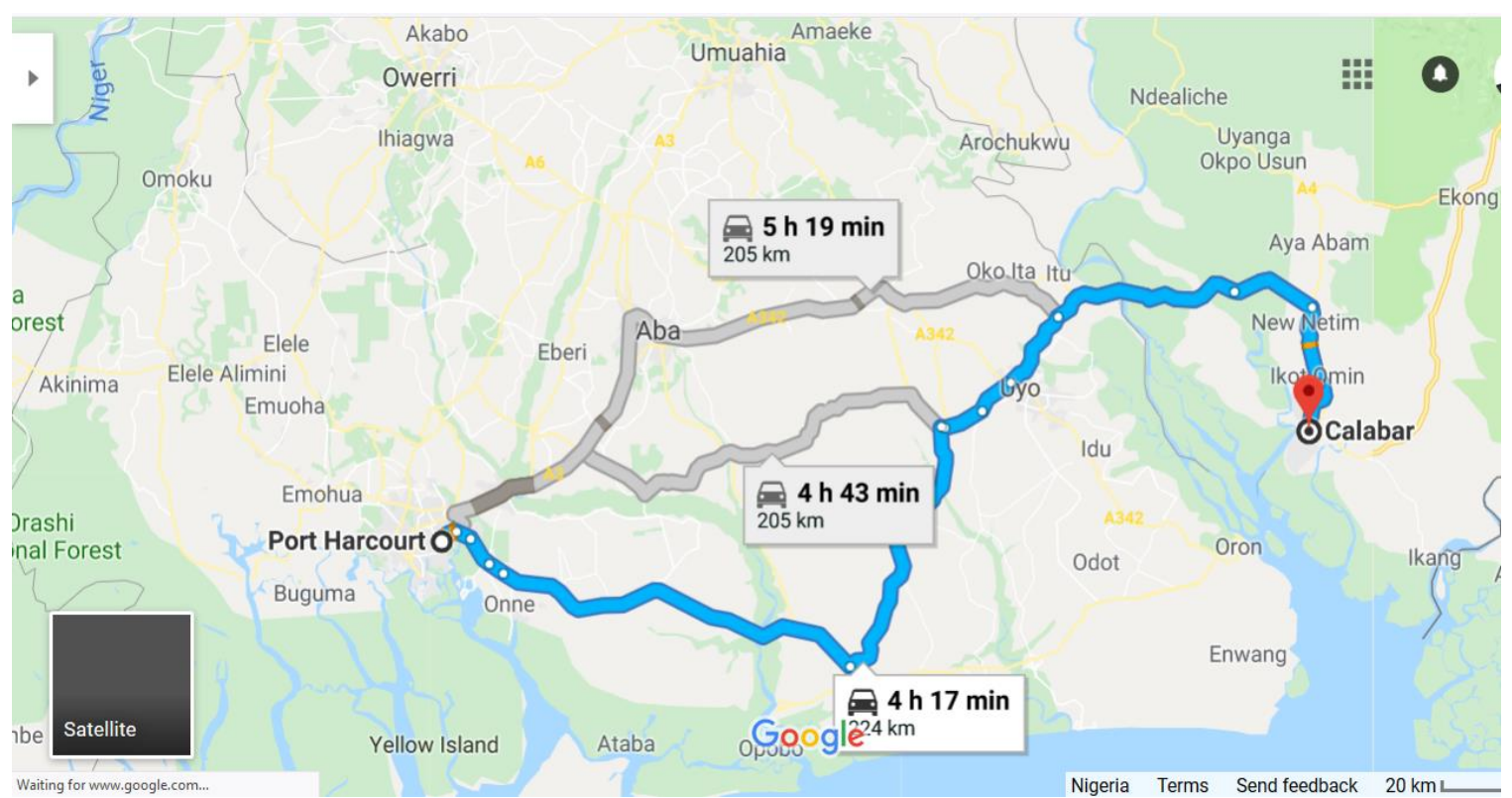

Fig. 1. Map showing distance between Port Harcourt and Calabar

Table 2. Representative day of each month for calculation of the monthly mean extraterrestrial solar radiation for Port Harcourt and Calabar [11]

\begin{tabular}{lllll}
\hline Month & $\mathrm{n}$ for $\mathrm{i}^{\text {th }}$ day of the month & Representative day & $\mathrm{n}$ & $\delta$ \\
\hline January & 1 & 17 & 17 & -20.9 \\
February & $\mathrm{i}+31$ & 16 & 47 & -13.0 \\
March & $\mathrm{i}+59$ & 16 & 75 & -2.4 \\
April & $\mathrm{i}+90$ & 15 & 105 & 9.4 \\
May & $\mathrm{i}+120$ & 15 & 135 & 18.8 \\
June & $\mathrm{i}+151$ & 11 & 162 & 23.1 \\
July & $\mathrm{i}+181$ & 17 & 198 & 21.2 \\
August & $\mathrm{i}+212$ & 16 & 228 & 13.5 \\
September & $\mathrm{i}+243$ & 15 & 258 & 2.2 \\
October & $\mathrm{i}+273$ & 15 & 288 & -9.6 \\
November & $\mathrm{i}+304$ & 14 & 318 & -18.9 \\
December & $\mathrm{i}+334$ & 10 & 344 & -23.0 \\
\hline
\end{tabular}

\subsection{Data Analysis}

In order to carry out the time series proposed for this study, astronomical trends were eliminated by dividing global solar radiation $(\mathrm{H})$ by the extraterrestrial solar radiation $\left(\mathrm{H}_{\mathrm{o}}\right)$. Trends removal in the global solar radiation was executed by subtracting the mean of the clearness index from the long-term monthly mean values of clearness indices for Port Harcourt and Calabar. Thus, the seasonal trend removal of solar radiation was evaluated using the following expressions.

$k t^{\prime}=k t-\langle k t\rangle$

Where $k t^{\prime}=$ deviations of monthly average of the daily clearness index; $\langle k t\rangle=$ grand average of $\mathrm{kt}$, and $\mathrm{kt}=$ clearness index (i.e., $\mathrm{H} / \mathrm{H}_{\mathrm{o}}$ ). The Kolmogorov-Smirnov normality and total auto-correlation functions tests were equally used to determine the deviation and interannual variability of solar radiation at Port Harcourt and Calabar. 


\section{Results and Discussion}

\subsection{Results}

The descriptive statistics of measured global solar radiation, calculated extraterrestrial solar radiation, and evaluated clearness indices for Port Harcourt and Calabar are shown in Tables $3-5$. Figures 2 and 3 present inter-monthly deviations of clearness indices for Port Harcourt and Calabar. In Figures 4 - 16, the series of annual and monthly anomalies of clearness indices for Port Harcourt and Calabar are shown. Tables 6 and 7 together with Figures 17 and 18 present the total auto-correlation functions in deviation of $\mathrm{km}-\langle\mathrm{km}\rangle$ for Port Harcourt and Calabar. Figures 19 and 20 show the condition of normality of clearness index deviation for Calabar and Port Harcourt.

Table 3. Descriptive statistics of monthly mean daily global solar radiation $\left(\mathrm{MJm}^{-2} \mathrm{day}^{-1}\right)$ for Port Harcourt and Calabar

\begin{tabular}{|c|c|c|c|c|c|c|c|c|}
\hline & N & Range & Minimum & Maximum & Sum & \multicolumn{2}{|c|}{ Mean } & $\begin{array}{c}\text { Std. } \\
\text { Deviation }\end{array}$ \\
\cline { 2 - 9 } & Statistic & Statistic & Statistic & Statistic & Statistic & Statistic & Std. Error & Statistic \\
\hline Port Harcourt & 12 & 5.16 & 12.87 & 18.03 & 185.88 & 15.4900 & .44056 & 1.52616 \\
Calabar & 12 & 5.17 & 12.60 & 17.77 & 187.69 & 15.6408 & .47382 & 1.64134 \\
Valid N & 12 & & & & & & & \\
(listwise) & & & & & & & \\
\hline
\end{tabular}

Table 4. Descriptive Statistics of monthly mean daily extraterrestrial solar radiation $\left(\mathrm{MJm}^{-2} \mathrm{day}^{-1}\right)$ for Port Harcourt and Calabar

\begin{tabular}{|c|c|c|c|c|c|c|c|c|}
\hline & $\mathrm{N}$ & Range & $\begin{array}{c}\text { Minimu } \\
\mathrm{m}\end{array}$ & $\begin{array}{c}\text { Maximu } \\
\mathrm{m}\end{array}$ & Sum & \multicolumn{2}{|c|}{ Mean } & $\begin{array}{c}\text { Std. } \\
\text { Deviation }\end{array}$ \\
\cline { 2 - 9 } & Statistic & Statistic & Statistic & Statistic & Statistic & Statistic & Std. Error & Statistic \\
\hline Calabar & 12 & 3.85 & 33.78 & 37.64 & 431.74 & 35.9784 & .34991 & 1.21213 \\
Port Harcourt & 12 & 3.87 & 33.78 & 37.65 & 431.85 & 35.9878 & .35078 & 1.21514 \\
Valid N & 12 & & & & & & & \\
(listwise) & 12 & & & & & & & \\
\hline
\end{tabular}

Table 5. Descriptive Statistics of monthly mean daily clearness index for Port Harcourt and Calabar

\begin{tabular}{|c|c|c|c|c|c|c|c|c|}
\hline & $\mathrm{N}$ & Range & Minimum & Maximum & Sum & \multicolumn{2}{|c|}{ Mean } & $\begin{array}{c}\text { Std. } \\
\text { Deviation }\end{array}$ \\
& Statistic & Statistic & Statistic & Statistic & Statistic & Statistic & Std. Error & Statistic \\
\hline Port Harcourt & 12 & .1635 & .3541 & .5176 & 5.1731 & .431088 & .0137923 & .0477779 \\
Calabar & 12 & .1656 & .3444 & .5100 & 5.2250 & .435419 & .0145954 & .0505600 \\
Valid N & 12 & & & & & & & \\
(listwise) & & & & & & & \\
\hline
\end{tabular}




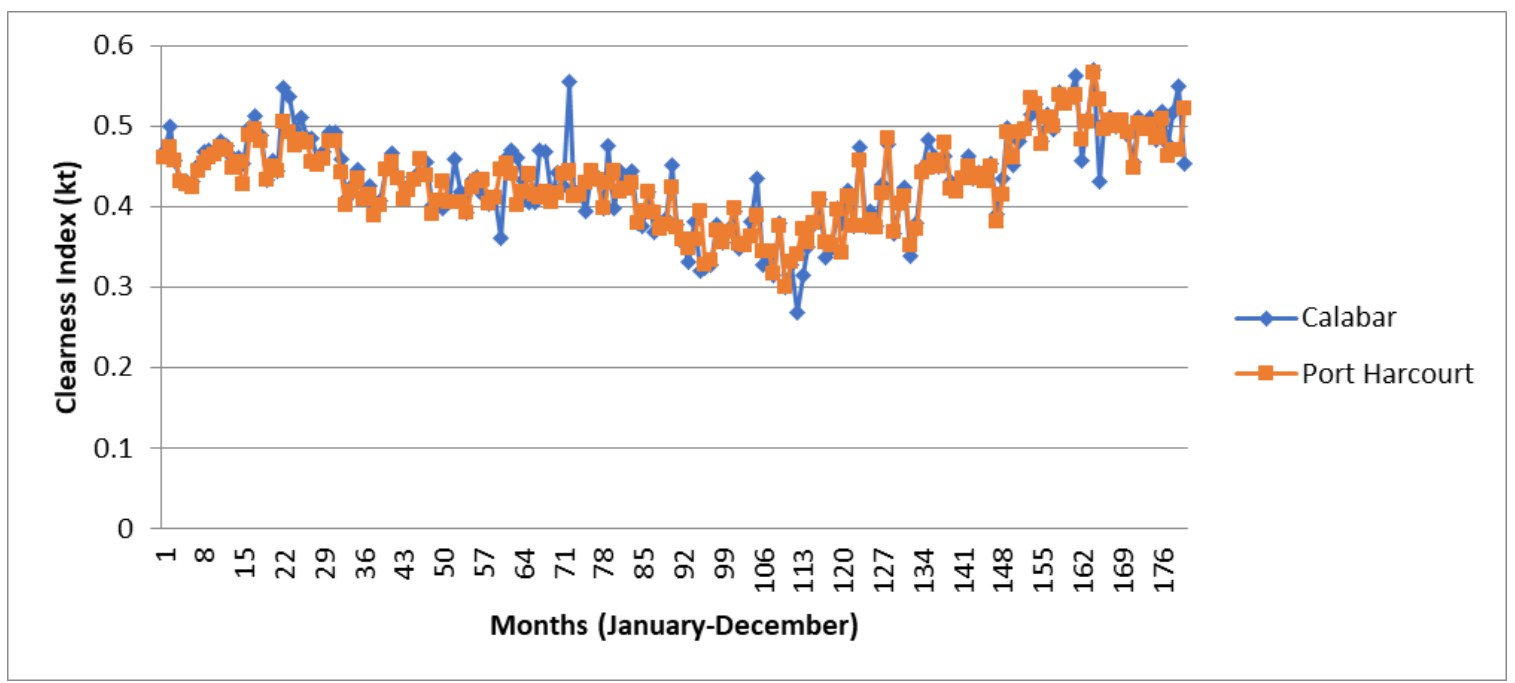

Fig. 2. Monthly mean daily clearness index (kt) deviation series for Port Harcourt and Calabar for January - December for fifteen years.

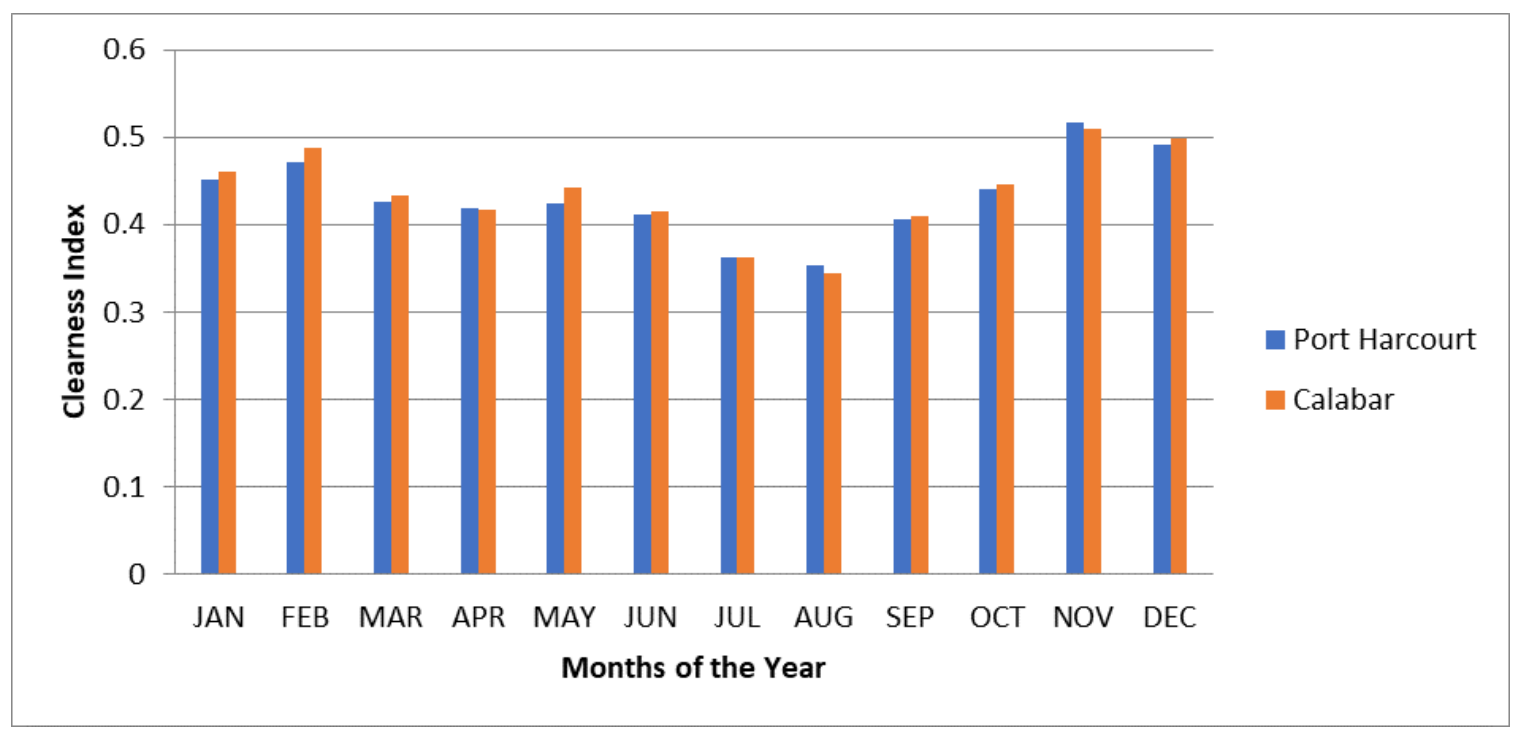

Fig. 3. Monthly mean daily clearness index deviation series for Port Harcourt and Calabar

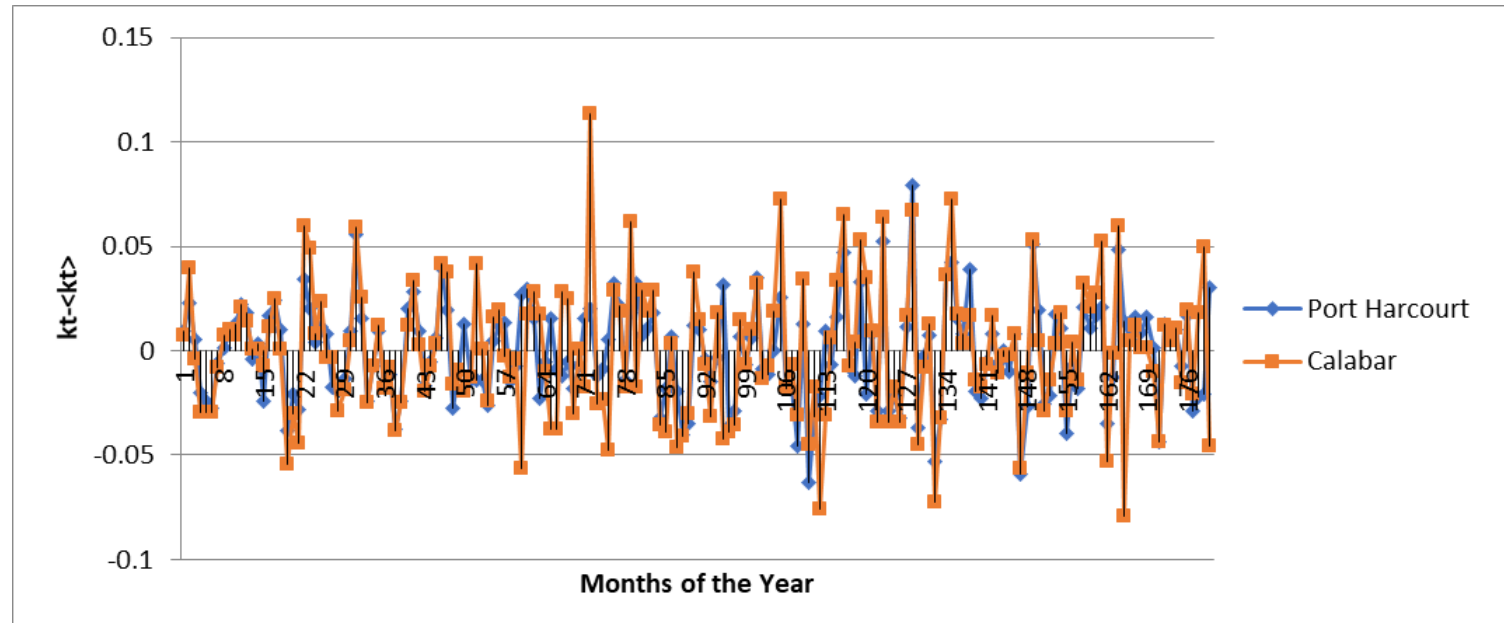

Fig. 4. Solar Radiation deviation series for Port Harcourt and Calabar for January - December for fifteen years. $\mathrm{Kt}=$ Annual monthly daily clearness index, $\langle\mathrm{kt}\rangle=$ average of $\mathrm{kt}$ 


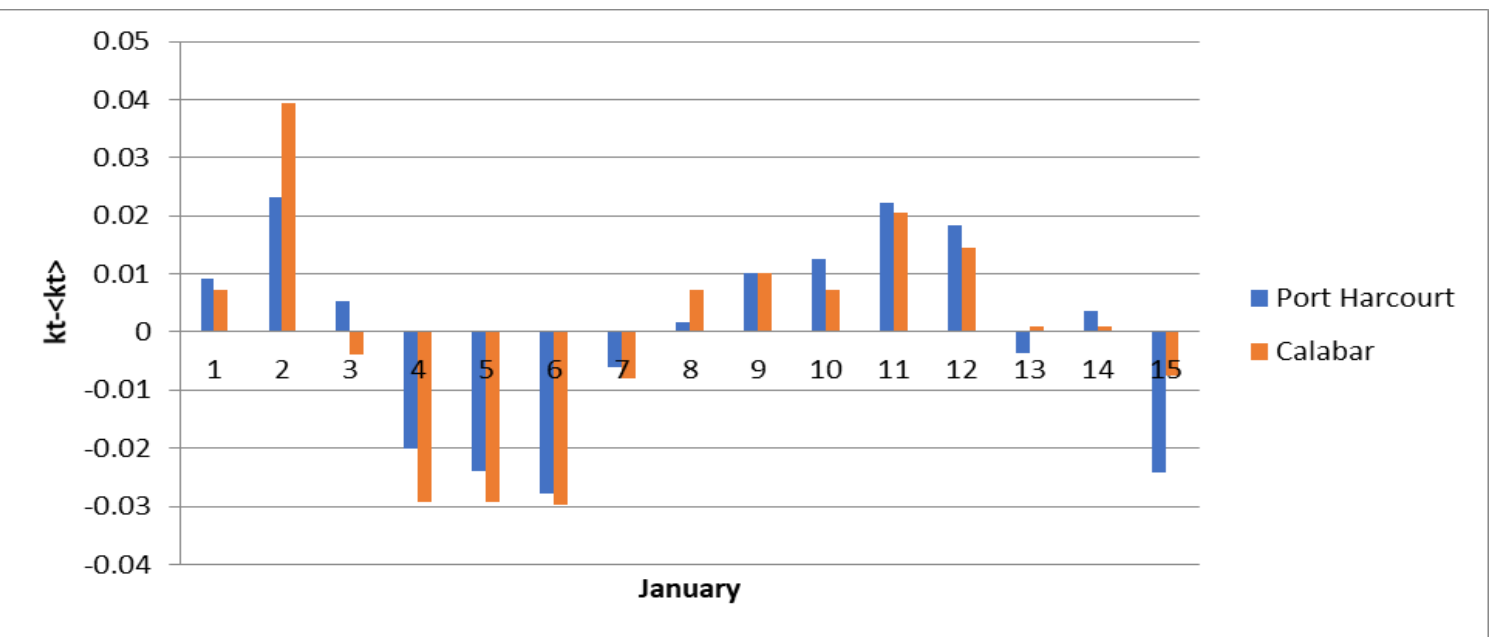

Fig. 5. Solar Radiation deviation series for Port Harcourt and Calabar for January for fifteen years. $\mathrm{Kt}=$ monthly mean daily clearness index, $\langle\mathrm{kt}\rangle=$ mean of $\mathrm{kt}$

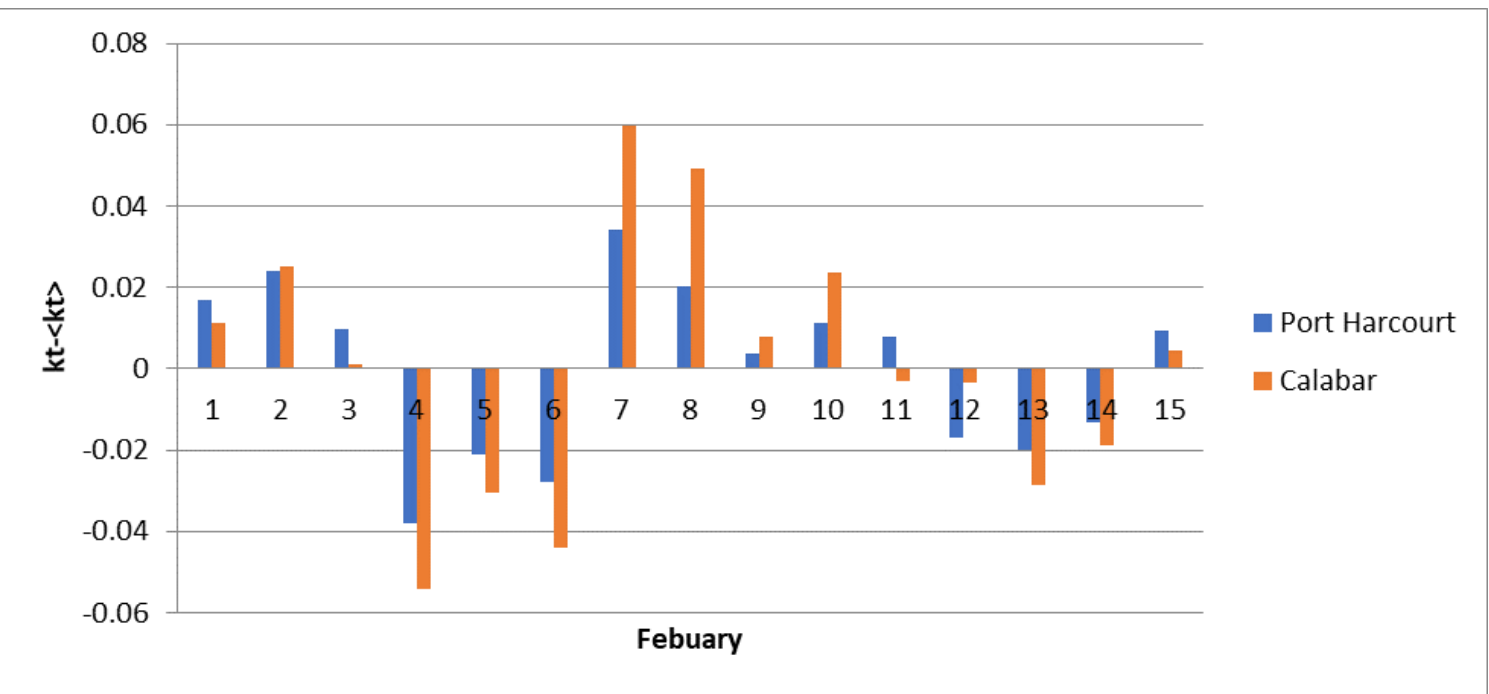

Fig. 6. Solar Radiation deviation series for Port Harcourt and Calabar for February for fifteen years. $\mathrm{Kt}=$ monthly mean daily clearness index, $\langle\mathrm{kt}\rangle=$ mean of $\mathrm{kt}$

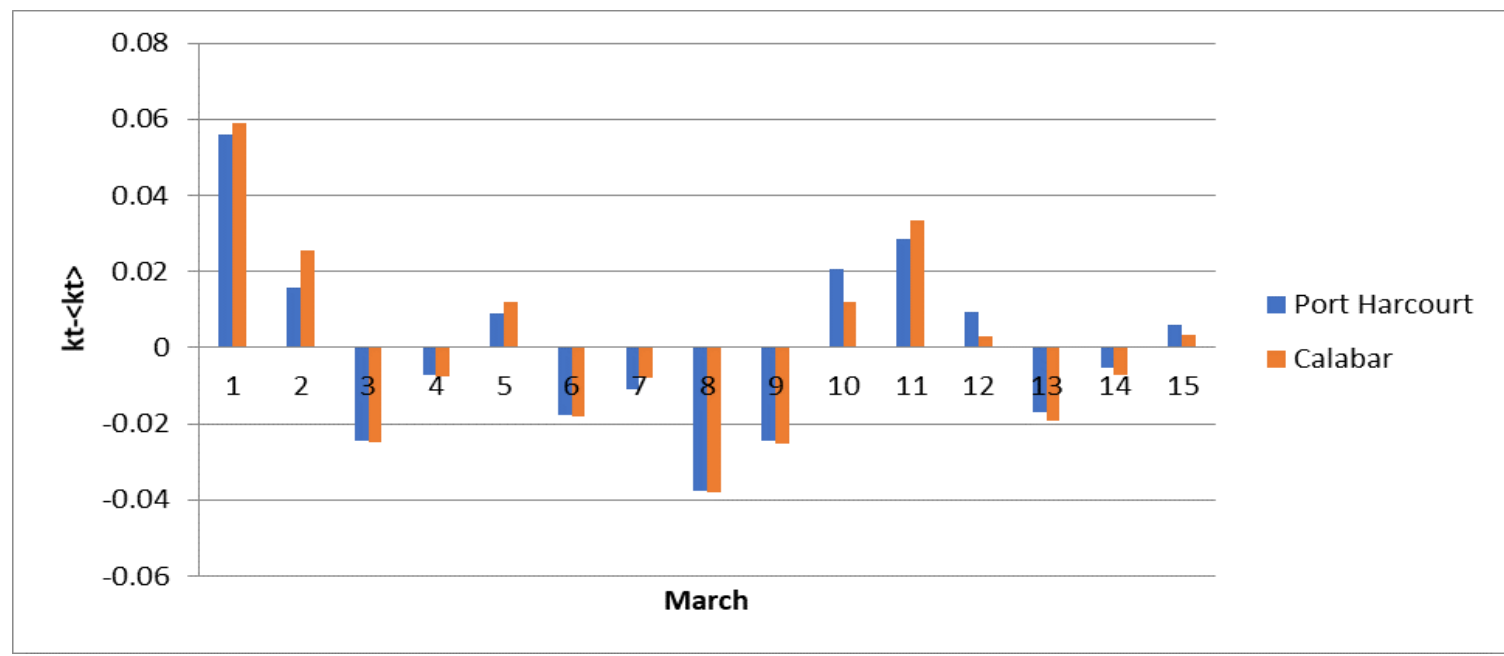

Fig. 7. Solar Radiation deviation series for Port Harcourt and Calabar for March for fifteen years. $\mathrm{Kt}=$ monthly mean daily clearness index, $\langle\mathrm{kt}\rangle=$ mean of $\mathrm{kt}$ 


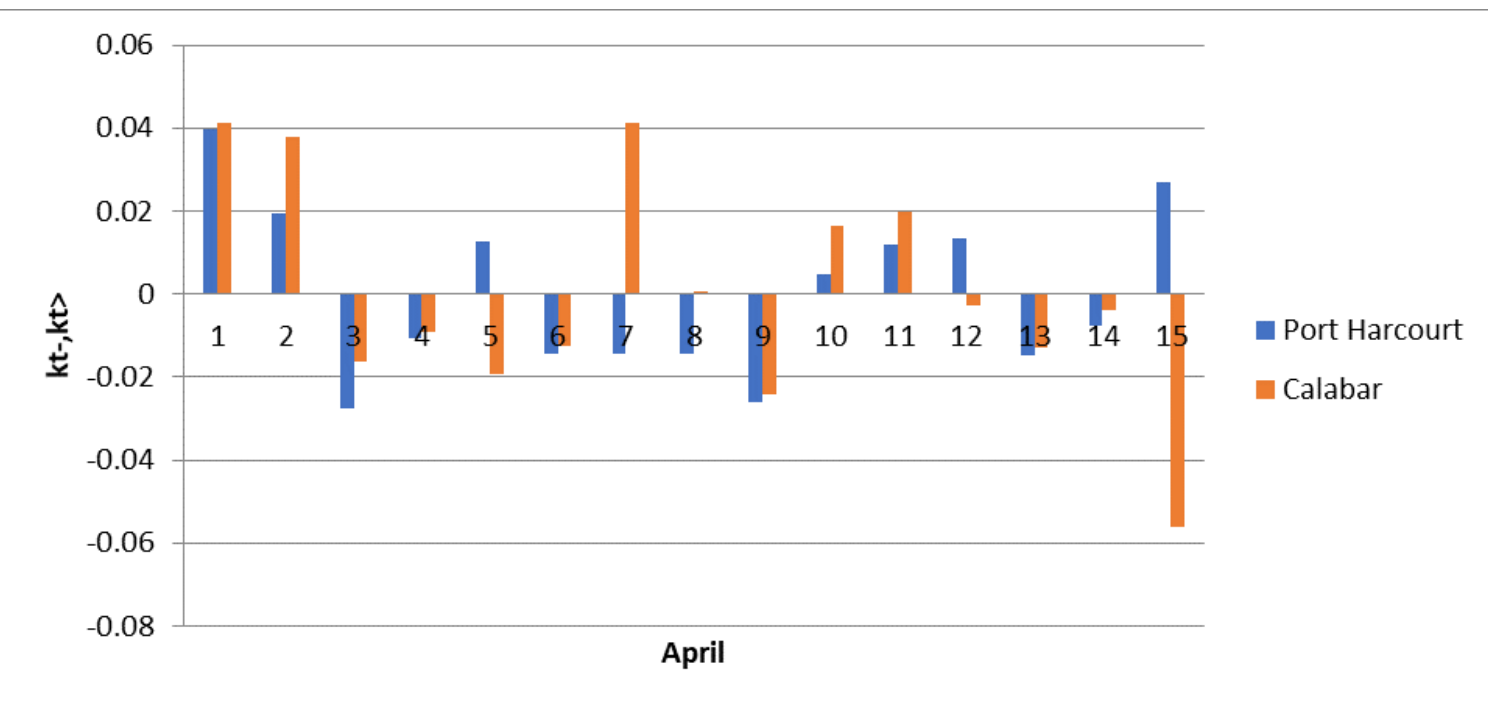

Fig. 8. Solar Radiation deviation series for Port Harcourt and Calabar for April for fifteen years. Kt $=$ monthly mean daily clearness index, $\langle\mathrm{kt}\rangle=$ mean of $\mathrm{kt}$

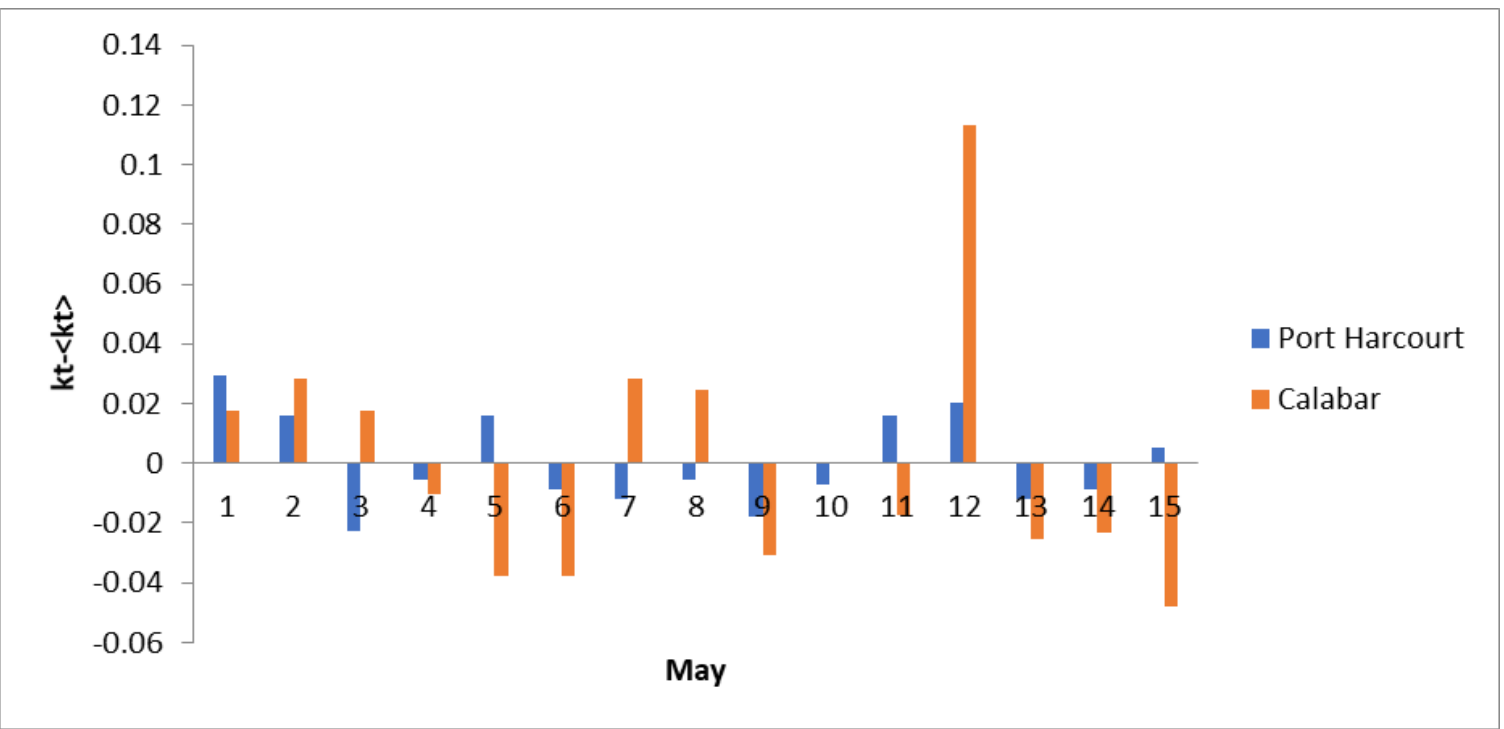

Fig. 9. Solar Radiation deviation series for Port Harcourt and Calabar for May for fifteen years. Kt $=$ monthly mean daily clearness index, $\langle\mathrm{kt}\rangle=$ mean of $\mathrm{kt}$ 


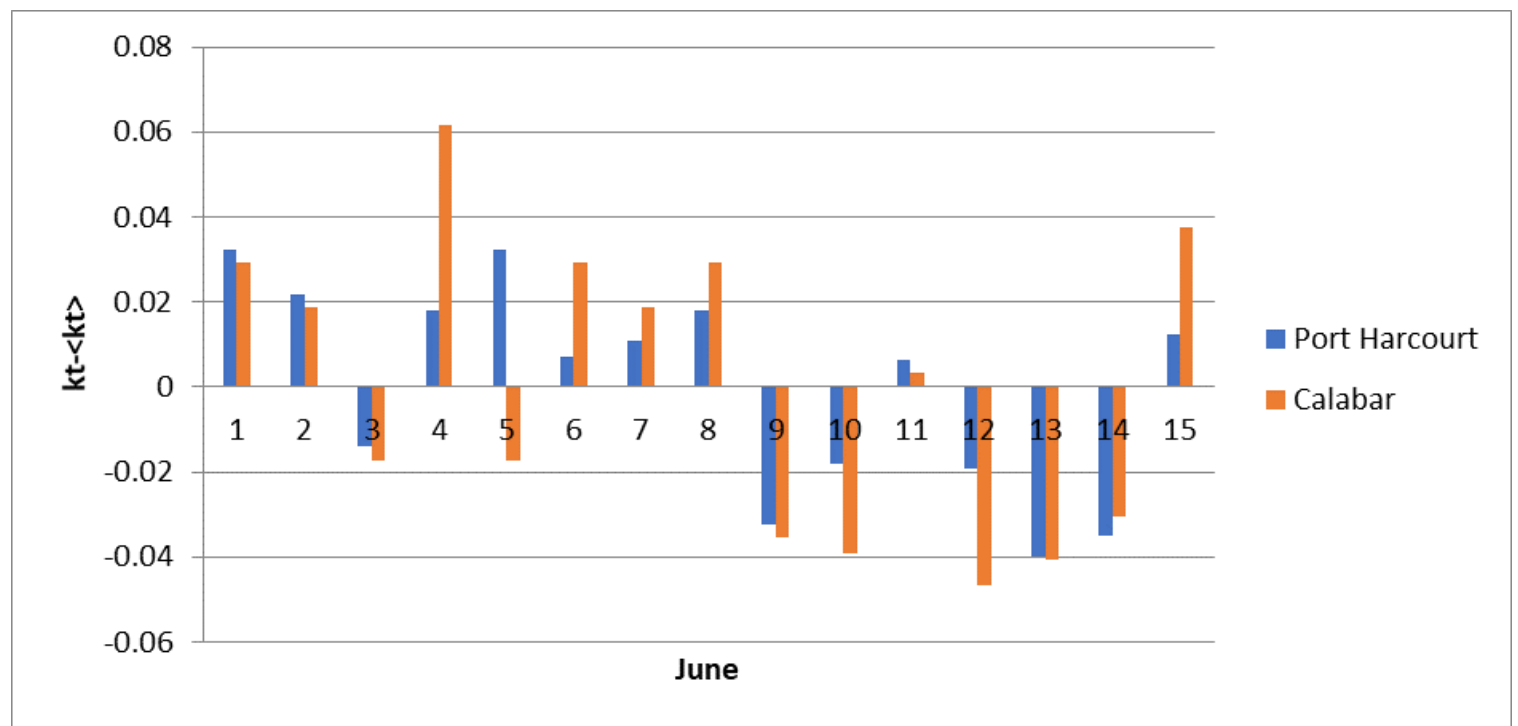

Fig. 10. Solar Radiation deviation series for Port Harcourt and Calabar for June for fifteen years. $\mathrm{Kt}=$ monthly mean daily clearness index,$<\mathrm{kt}>=$ mean of $\mathrm{kt}$

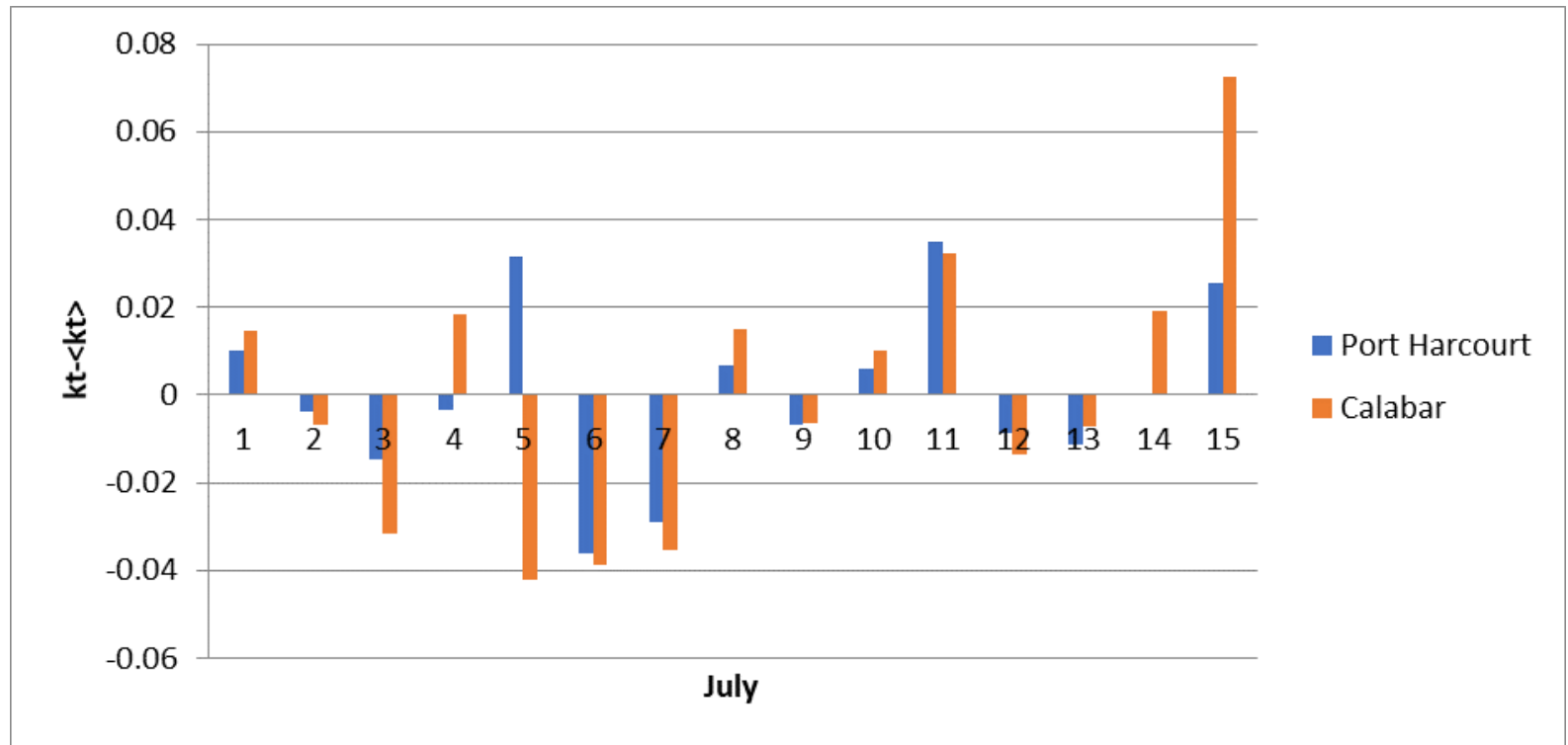

Fig. 11. Solar Radiation deviation series for Port Harcourt and Calabar for July for fifteen years. $\mathrm{Kt}=$ monthly mean daily clearness index, $\langle\mathrm{kt}\rangle=$ mean of $\mathrm{kt}$ 


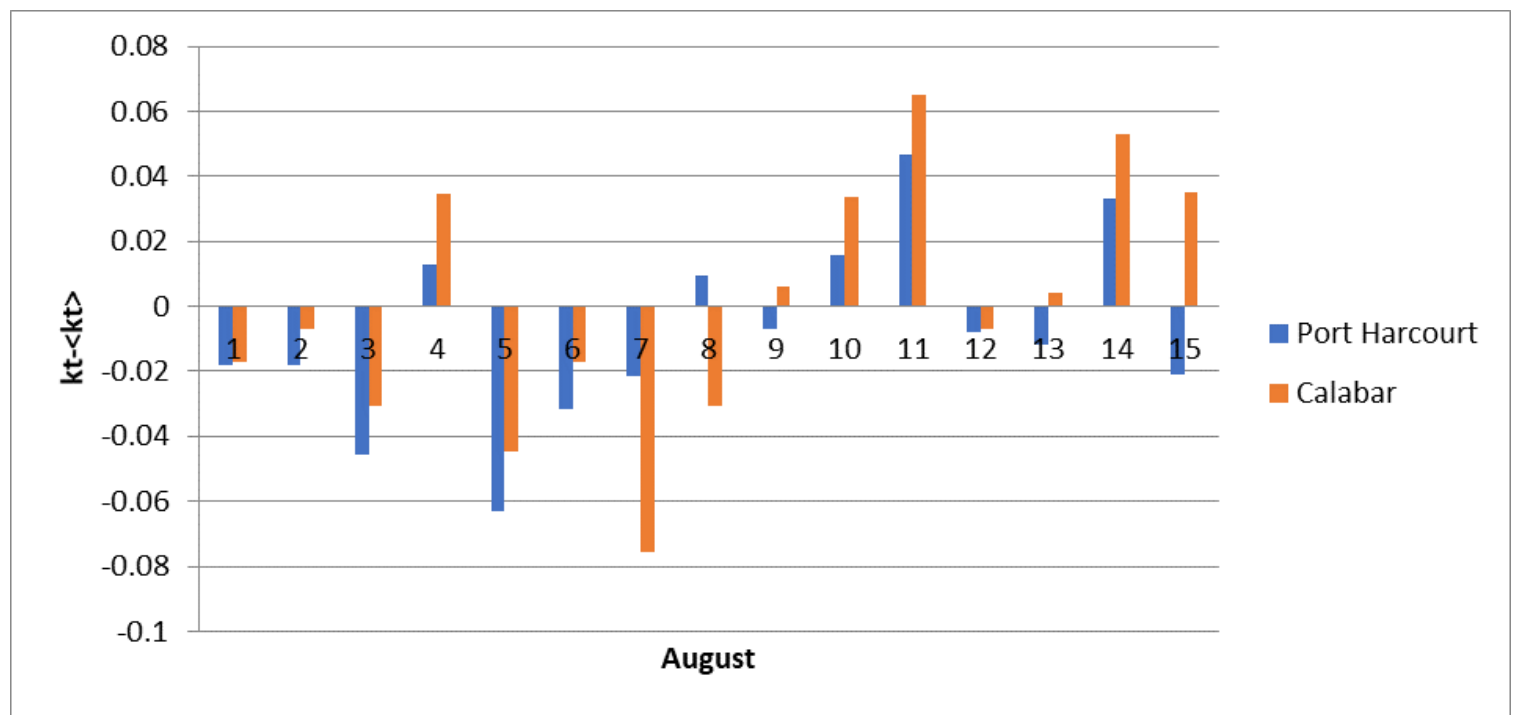

Fig. 12. Solar Radiation deviation series for Port Harcourt and Calabar for August for fifteen years. $\mathrm{Kt}=$ monthly mean daily clearness index, $\langle\mathrm{kt}\rangle=$ mean of $\mathrm{kt}$

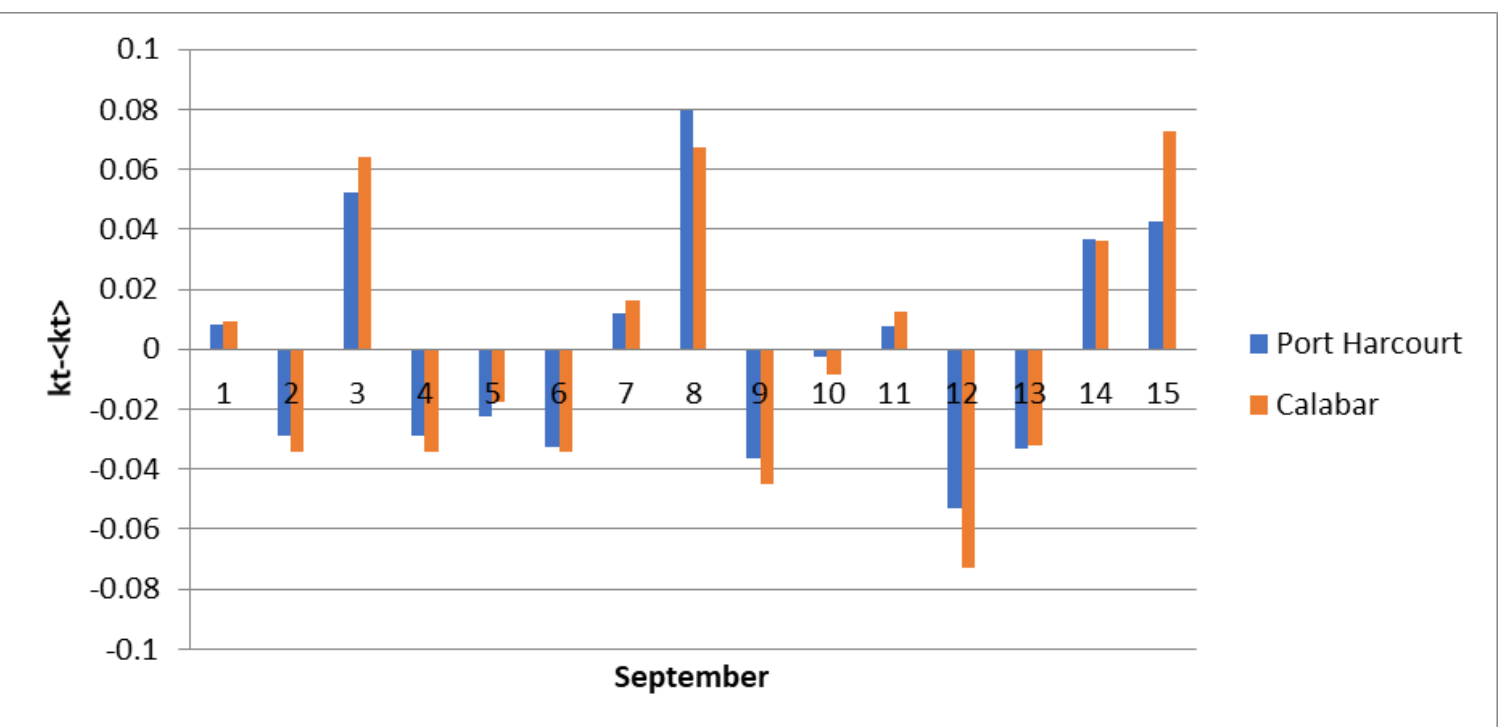

Fig. 13. Solar Radiation deviation series for Port Harcourt and Calabar for September for fifteen years.

$\mathrm{Kt}=$ monthly mean daily clearness index, $\langle\mathrm{kt}\rangle=$ mean of $\mathrm{kt}$ 


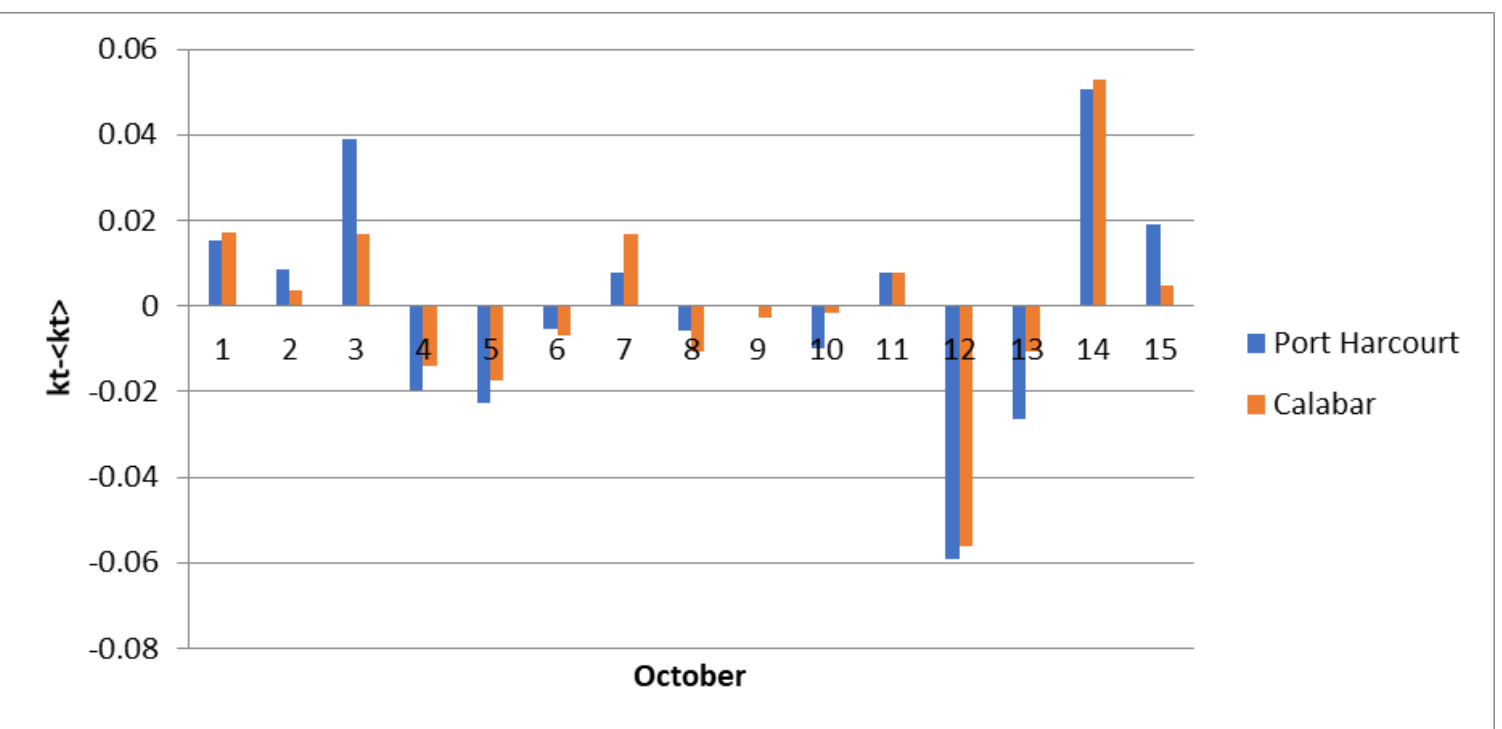

Fig. 14. Solar Radiation deviation series for Port Harcourt and Calabar for October for fifteen years.

$\mathrm{Kt}=$ monthly mean daily clearness index, $<\mathrm{kt}>=$ mean of $\mathrm{kt}$

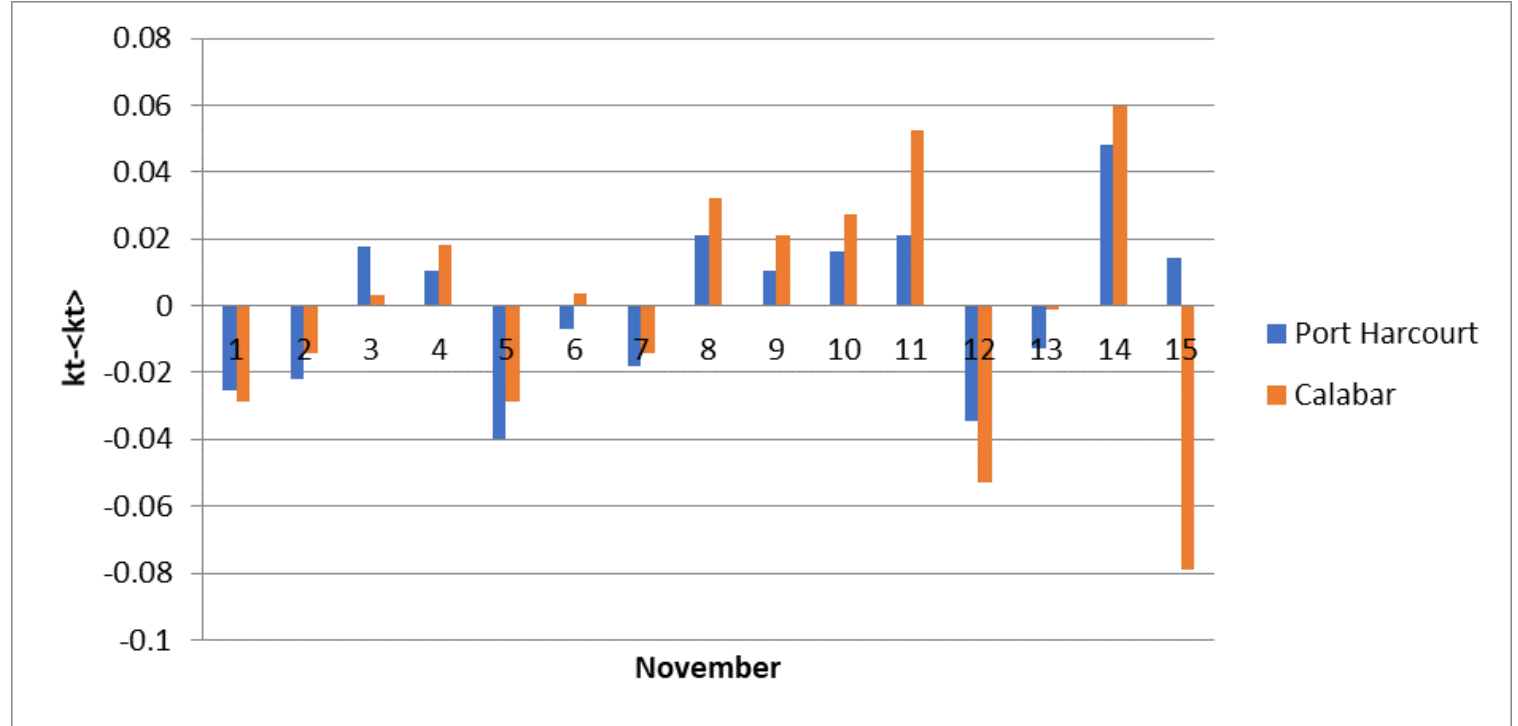

Fig. 15. Solar Radiation deviation series for Port Harcourt and Calabar for November for fifteen years.

$\mathrm{Kt}=$ monthly mean daily clearness index, $<\mathrm{kt}>=$ mean of $\mathrm{kt}$ 


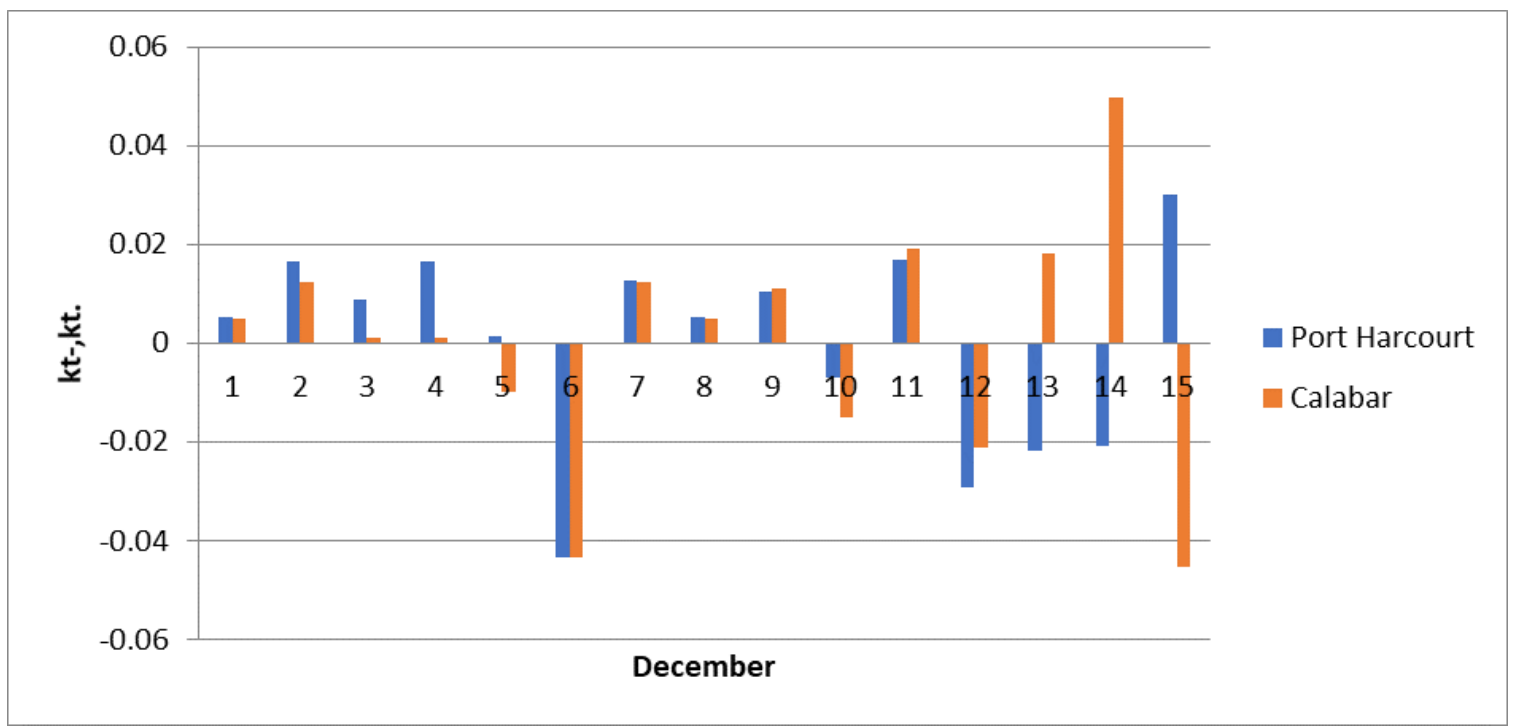

Fig. 16. Solar Radiation deviation series for Port Harcourt and Calabar for December for fifteen years.

$\mathrm{Kt}=$ monthly mean daily clearness index,$<\mathrm{kt}>=$ mean of $\mathrm{kt}$

Table 6. Total auto-correlation function in deviation series of $\mathrm{km}-<\mathrm{km}>$ for Port Harcourt

\begin{tabular}{|c|c|c|c|c|c|}
\hline \multirow{2}{*}{ Lag } & \multirow{2}{*}{ Autocorrelation } & \multirow{2}{*}{ Std. Error } & \multicolumn{3}{|c|}{ Box-Ljung Statistic } \\
\cline { 3 - 6 } & & & Value & df & Sig. \\
\hline 1 & .108 & .074 & 2.144 & 1 & .143 \\
2 & -.216 & .074 & 10.722 & 2 & .005 \\
3 & -.106 & .074 & 12.802 & 3 & .005 \\
4 & .063 & .073 & 13.537 & 4 & .009 \\
5 & -.057 & .073 & 14.135 & 5 & .015 \\
6 & -.094 & .073 & 15.794 & 6 & .015 \\
7 & -.003 & .073 & 15.796 & 7 & .027 \\
8 & -.002 & .072 & 15.796 & 8 & .045 \\
9 & -.088 & .072 & 17.269 & 9 & .045 \\
10 & .006 & .072 & 17.275 & 10 & .068 \\
11 & .004 & .072 & 17.278 & 11 & .100 \\
12 & -.065 & .072 & 18.094 & 12 & .113 \\
13 & -.275 & .071 & 32.933 & 13 & .002 \\
14 & .154 & .071 & 37.620 & 14 & .001 \\
15 & .392 & .071 & 68.054 & 15 & .000 \\
16 & -.011 & .071 & 68.077 & 16 & .000 \\
\hline
\end{tabular}

a. The underlying process assumed is independence (white noise).

b. Based on the asymptotic chi-square approximation. 


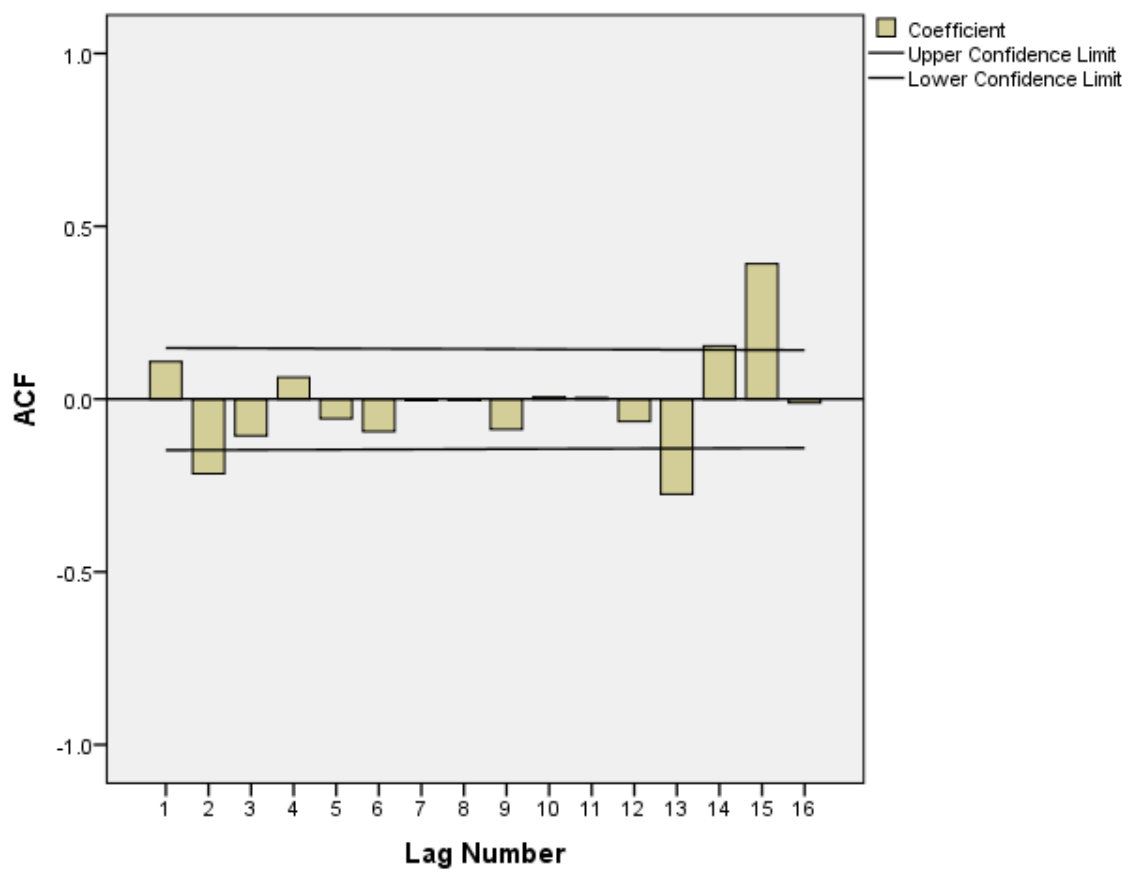

Fig. 17. Total auto-correlation function in deviation series of $\mathrm{km}-<\mathrm{km}>$ for Port Harcourt

Table 7. Total auto-correlation function in deviation series of $\mathrm{km}-<\mathrm{km}>$ for Calabar

\begin{tabular}{|c|c|c|c|c|c|}
\hline \multirow{2}{*}{ Lag } & \multirow{2}{*}{ Autocorrelation } & \multirow{2}{*}{ Std. Error ${ }^{\mathrm{a}}$} & \multicolumn{3}{|c|}{ Box-Ljung Statistic } \\
\cline { 4 - 6 } & & & Value & $\mathrm{df}$ & Sig. $^{\mathrm{b}}$ \\
\hline 1 & .031 & .074 & .171 & 1 & .679 \\
3 & -.149 & .074 & 4.281 & 2 & .118 \\
4 & -.135 & .074 & 7.650 & 3 & .054 \\
5 & -.013 & .073 & 7.680 & 4 & .104 \\
6 & -.014 & .073 & 7.716 & 5 & .173 \\
7 & -.115 & .073 & 10.226 & 6 & .115 \\
8 & -.015 & .073 & 10.268 & 7 & .174 \\
9 & -.078 & .072 & 11.440 & 8 & .178 \\
10 & .030 & .072 & 11.611 & 9 & .236 \\
11 & .019 & .072 & 11.678 & 10 & .307 \\
12 & .050 & .072 & 12.158 & 11 & .352 \\
13 & -.075 & .072 & 13.256 & 12 & .351 \\
14 & -.197 & .071 & 20.874 & 13 & .075 \\
15 & .070 & .071 & 21.843 & 14 & .082 \\
16 & .298 & .071 & 39.448 & 15 & .001 \\
\hline
\end{tabular}

a. The underlying process assumed is independent (white noise).

b. Based on the asymptotic chi-square approximation. 


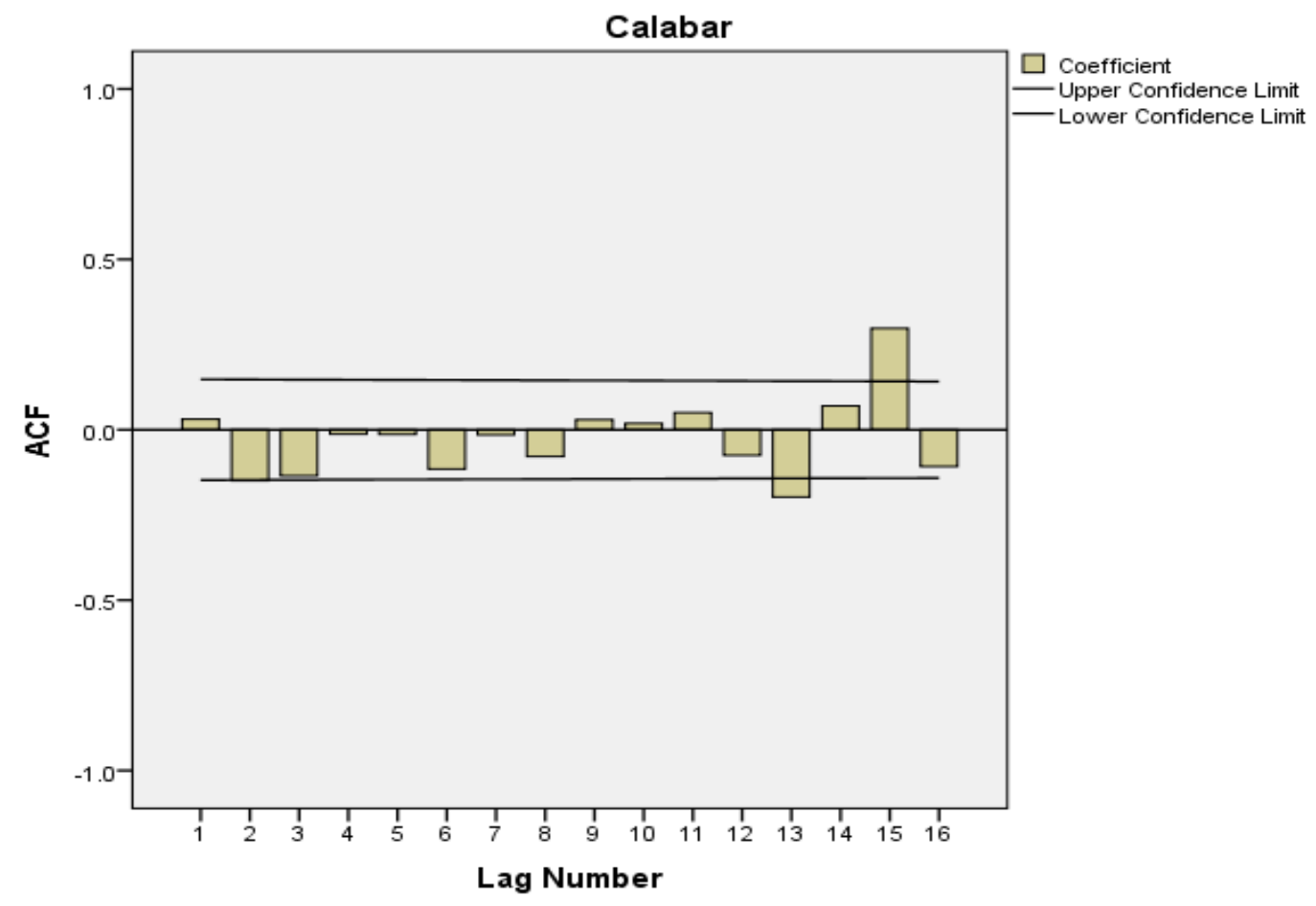

Fig. 18. Total auto-correlation function in deviation series of $\mathrm{km}-<\mathrm{km}>$ for Calabar

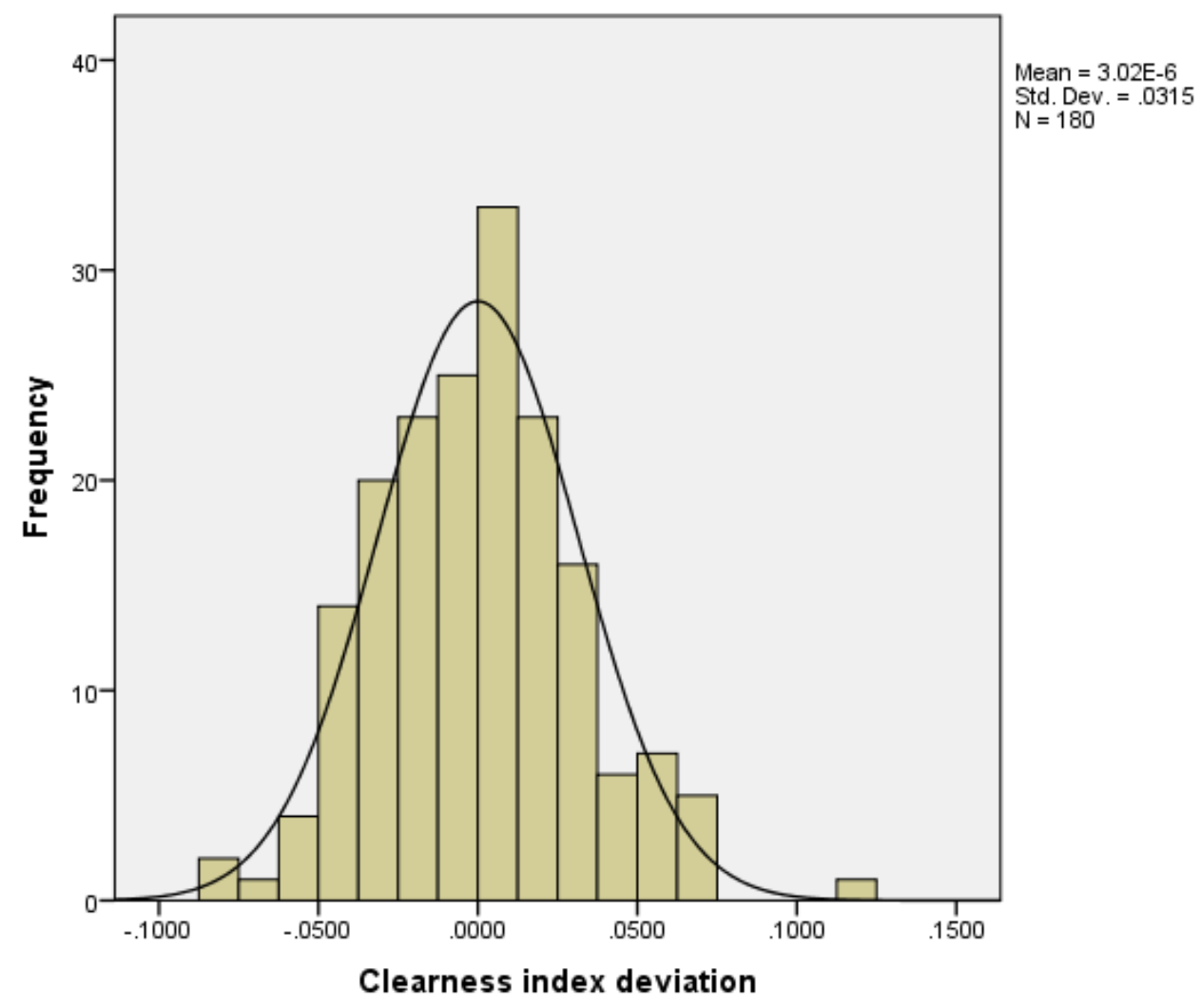

Fig. 19. Normality condition (Gaussian distribution) for clearness index deviation for Calabar 


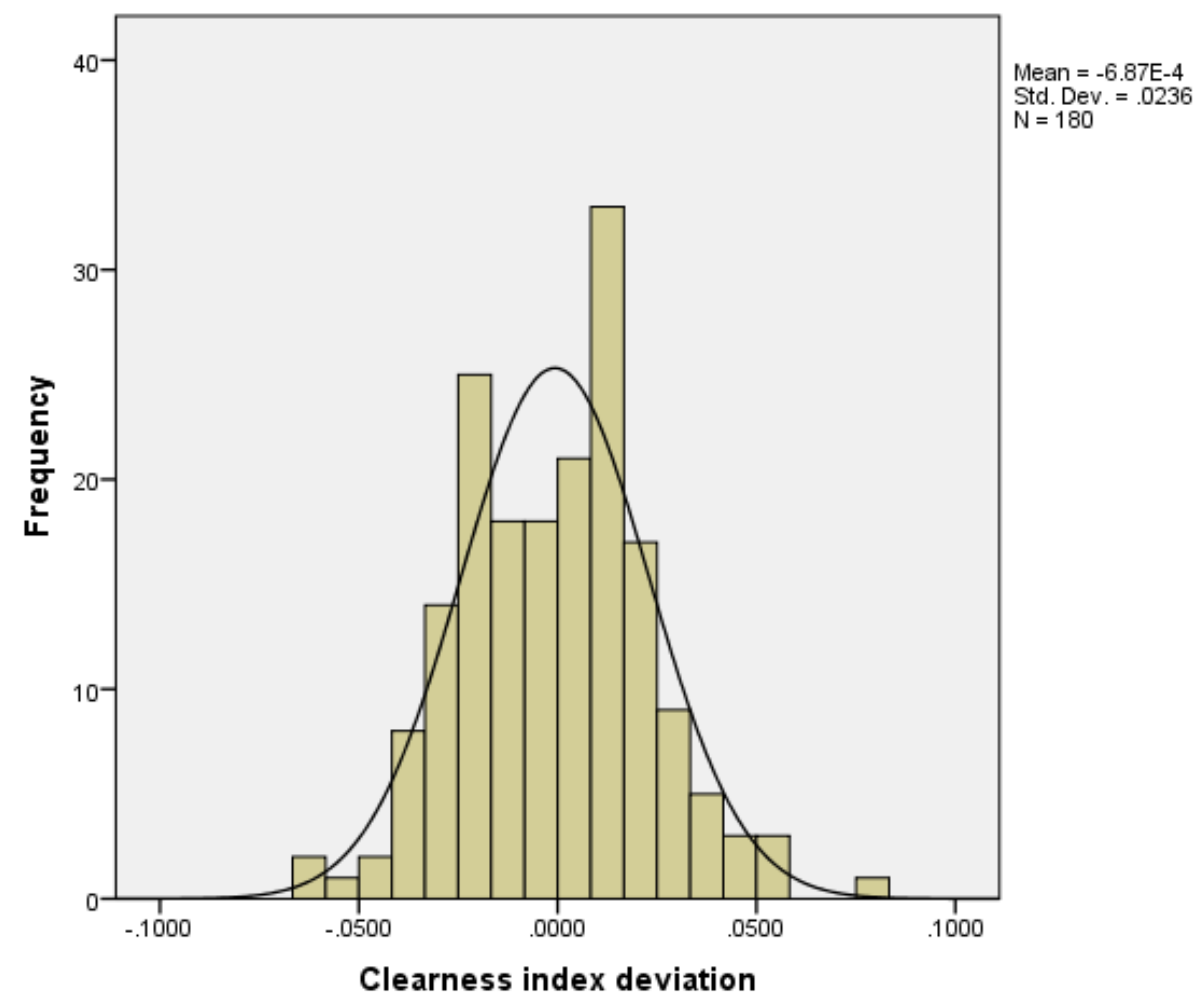

Fig. 20. Normality condition (Gaussian distribution) for clearness index deviation for Port Harcourt

\subsection{Discussion}

A close examination of Tables 3 and 4 shows that the maximum values of the monthly mean daily global solar radiation on a horizontal surface and the monthly mean daily extraterrestrial solar radiation for Port Harcourt are $18.03 \mathrm{MJm}^{-2} \mathrm{day}^{-1}$ and 37.65 $\mathrm{MJm}^{-2} \mathrm{day}^{-1}$, respectively, whereas $17.77 \mathrm{MJm}^{-2} \mathrm{day}^{-1}$ and $37.64 \mathrm{MJm}^{-2} \mathrm{day}^{-1}$ were registered for Calabar, respectively. High values of monthly mean daily global solar radiation for the two cities were observed in the dry season months of November to April with peaks in November and February. There is a drop in December and January values of global solar radiation in the two cities, because of the Harmattan that reaches its peak from December to January. The months of occurrence is expected because high values of global solar radiation obtained during the dry season at the study location can be attributed to many contributory factors. The fact that the earth is closest to the sun in early January (The perihelion) than any other time is one significant factor. This observation is also attributed to the prevalence of low smog, low relative humidity, low cloud cover, low reflection, scattering and absorption by clouds together with low absorption of diffuse solar radiation and near infrared component of the solar spectrum during the November - February months. This period is markedly dry at these locations. Combination of all these factors enhances the global solar radiation and clearness index received at these locations. Furthermore, Harmattan is not usually severe in these areas compared to other cities further inland. Therefore, the aerosol mass loading that characterizes the Harmattan season (majorly months of November to February in Nigeria) is not seriously pronounced in these cities, thereby increasing greatly the intensity of daily global solar radiation on a flat surface within the months of November 
to February. Nevertheless, Harmattan reaches its peak from December to January in these cities, causing a drop in monthly average daily global solar radiation from December to January. The Harmattan season is usually connected with the prevalence of thick dust haze and early morning fog and mist resulted from the radiation cooling in the night under clear skies. This result is in agreement with Amadi et al [12], which observed that Calabar and Port Harcourt experience the highest number of sunshine hours in the November to February months. These results are also in consonance with the literature $[13,14]$. These trends are similar to the reports of several research in the region which lies within tropical rainforest zone of Nigeria [15-21].

It can be observed from Table 3 that the maximum global solar radiation received at Port Harcourt $\left(18.03 \mathrm{MJm}^{-2} \mathrm{day}^{-1}\right)$ and Calabar $\left(17.77 \mathrm{MJm}^{-2} \mathrm{day}{ }^{-1}\right)$ are at par with each other. Similar observation also goes for the minimum values of global solar radiation received at the two cities (12.87 $\mathrm{MJm}^{2} \mathrm{day}^{-1}$ and $\left.12.60 \mathrm{MJm}^{2} \mathrm{day}^{-1}\right)$ for Port Harcourt and Calabar, respectively. However, while the minimum was observed at Port Harcourt in July, it was observed at Calabar in August. A cursory look at Table 4 shows that the values of the maximum and minimum monthly mean daily global solar radiation received at Port Harcourt (37.65 $\mathrm{MJm}^{2} \mathrm{day}^{-1}$ and $33.78 \mathrm{MJm}^{2} \mathrm{day}^{-1}$ ) and Calabar (37.64 $M \mathrm{Mm}^{2} \mathrm{day}^{-1}$ and $33.78 \mathrm{MJm}^{2} d a \mathrm{y}^{-1}$ ) are at par. Perhaps, the attenuation effects of aerosols, water vapour and low-level clouds on direct normal irradiance [22, 23] share some similar features in the two cities, since they are both coastal cities. Being coastal cities, they are highly affected by water drops aerosols, high load of sea salts and water vapour loads. The two cities are both administrative and commercialized with associated high load of atmospheric aerosols. Perhaps this explains why the clearness index variations and solar radiation deviation series in Figs 2, 3 and 4 follow the same pattern. However, Port Harcourt has more manufacturing concerns and is more industrialized. The city and its suburbs play host to many up-stream, middle-stream and down-stream oil industry activities being the hub of oil industry activities in Nigeria. The subsequent release of environmental pollutants such as greenhouse gases and aerosols (notably soot aerosols) would induce changes which determine to a great extent the degree of inter-annual variability of solar radiation and its components in the city. The result of higher attenuation effect of aerosols on solar radiation in Port Harcourt is vividly captured in Fig 3 , where the monthly mean clearness indices of Calabar for the 15 years period is always higher than that of Port Harcourt, except for the months of July, August and November. This observation in Port Harcourt clearness index in July, August and November could be attributed to the indirect effects of aerosols on clouds and precipitation. Large aerosol particles are efficiently removed by the washout mechanism which occurs when such aerosols are cloud condensation nuclei. The cloud droplets that form on such aerosol particles return them to the earth's surface which is their main atmospheric sink. This scavenging of the atmospheric aerosols increases the atmospheric transparency in the peak of rainy season in July and August in the area. The semi-direct effect of aerosol has to do with aerosols of soot origin (particulate black carbon) which absorb solar radiation and re-radiate it as thermal radiation inside cloud layers. This consequently heats the air mass and evaporates cloud droplets [24]. This perhaps causes higher transmissivity of the Port Harcourt atmosphere than that of Calabar in November when the rains cease.

It also necessary to state that the degree of surrounding ecological factors such as tree canopies, forest, green fields and vegetation equally converts the direct component of global solar radiation into photosynthetically active radiation needed by plants and crops 
for manufacturing food in the areas [25-27]. Thus, these factors are equally fundamental parameters that modify the global solar radiation and inter-annual variability of monthly mean global solar radiation and clearness index deviations in Port Harcourt and Calabar irrespective of the fact that the extraterrestrial solar radiation, elevation and latitude of Calabar and Port Harcourt are similar, with both cities sharing the same eco-climatic zone. These deviations are shown in Figures $2-16$.

The minimum values of extraterrestrial solar radiation $\left(33.78 \mathrm{MJm}^{-2} \mathrm{day}^{-1}\right.$ and $\left.33.78 \mathrm{MJm}^{-2} \mathrm{day}^{-1}\right)$ and global solar radiation $\left(12.87 \mathrm{MJm}^{-2} \mathrm{day}^{-1}\right.$ and 12.60 $\mathrm{MJm}^{-2} \mathrm{day}^{-1}$ ) obtained during the rainy season in the months of July and August respectively for Port Harcourt and Calabar is equally expected for a tropical site [14]. The months in which they occur are also expected, because the atmosphere in those months is characterized by higher cloud cover, high relative humidity and associated scattering and absorption of direct and diffuse radiation in the solar wave band, thereby producing low amount of global solar radiation intercepted at the site. These trends align with the reports of many solar energy researchers in the region which is the tropical rainforest ecological zone of Nigeria [15-21].

The average of the monthly clearness index describes the percentage depletion of the incident global solar radiation by the sky, and therefore displays both the amount of available solar radiation and variations in the condition of the atmosphere at a particular locality. The prevailing clearness index variation is within the range of $0.35-0.45$ for Port Harcourt and $0.34-0.46$ for Calabar within the April to October months in the wet season; 0.43 - 0.52 for Port Harcourt and $0.44-0.51$ for Calabar within the November to March months in the dry season, with an annual value of 0.43 for Port Harcourt and 0.44 for Calabar. The clearness index statistics is displayed in Table 5. These values are similar to some other reports in the same region of tropical rainforest eco-climatic zone of Nigeria [15-21].

Using the weather classification suggested by Iqbal [28] which are: (1) heavily overcast weather $(\mathrm{kt} \leq 0.4)$; (2) partly overcast weather $(0.4 \leq \mathrm{kt} \leq 0.6)$; and (3) clear weather $(\mathrm{kt} \geq 7)$, Port Harcourt and Calabar fall within the combination of heavily overcast weather and partly overcast weather. However, on the average, the cities have partly overcast weather. During the November to April months, the weather condition is clearly partly overcast. It was observed that global solar radiation varies directly with the clearness index and it increases very quickly as the heavily overcast sky becomes clearer. This is a demonstration that the clearness index has optimal control over global solar radiation at Port Harcourt and Calabar, Nigeria.

In Tables 6 and 7 and Figures 17 - 18, the illustrations of total auto-correlation functions for Port Harcourt and Calabar are displayed. The total auto-correlation shows vividly the seasonality of the coefficients; although showing some seasonality, it is much smaller. Where the auto-correlation coefficient with a given lag is situated externally in relation to the vertical lines, it can be confirmed, up to the $95 \%$ confidence level, that it is different from zero.

The solar radiation deviations analysis tested using the Kolmogorov-Smirnov method indicates that they are normally distributed random variables. Figures $19-20$ show that for Port Harcourt and Calabar, the monthly mean solar radiation deviations are normally distributed. Furthermore, the analysis of sequential properties reveals that the autocorrelation coefficients with lag 1 are significant for Port Harcourt. In Calabar, the 
correlation of monthly values does not show any clear regional configuration; so it is pertinent to remark that in these cases, Calabar is related to Port Harcourt. Generally, the auto-correlation coefficients with lag 1, though they are not significant, are negative for almost all the Port Harcourt and Calabar. These trends are consistent with the reports of many solar energy researchers in Brazil [29-32].

\section{CONCLUSIONS}

In this study, the characteristics of inter-annual variability of solar radiation were analyzed for Port Harcourt and Calabar. To do this, fifteen years $(2000$ - 2014) monthly mean global solar radiation were collected from NIMET while the monthly mean extraterrestrial solar radiation were calculated from standard relation recognized globally. Clearness index parameter was employed for characterizing the spatial variability of solar radiation for Port Harcourt and Calabar. From the results, Calabar and Port Harcourt received similar amounts of solar radiation. However, the stations recorded different degrees of inter-annual variability over the fifteen years period. The result revealed that solar radiation at Calabar deviates more than that of Port Harcourt as a result of anthropogenic, environmental, geographical and ecological influence on the transmissivity and optical properties of the atmosphere. The statistics for the monthly average solar radiation deviations for Port Harcourt and Calabar were tested using the Kolmogorov-Smirnov method. The test results portray them as normally distributed random variables.

\section{CONFLICTS OF INTEREST}

The authors declare that there is no conflict of interests regarding the publication of this paper

\section{REFERENCES}

[1] Okogbue, E. C. and Adedokun, J. A. (2002). On the estimation of solar radiation in Ondo. Nigerian Journal of Physics, 14, 97-99.

[2] Aklaque, A. M., Firoz, A. and Wasim, M. A. (2009). Estimation of global and diffuse solar radiation for Hyderabad, Sindh, Pakistan. Journal of Basic and Applied Science, 5(2), 73-77.

[3] Augustine, C. and Nnabuchi, M. N. (2010). Analysis of some meteorological data for some selected cities in the eastern and southern zones of Nigeria. African Journal of Environmental Science and Technology, 4(2), 92-99.

[4] Offiong, A. (2003). Assessing the economic and environmental prospects of stand-by solar powered systems. Nigeria. J. Applied Sci. and Env. Management, 7(1), 37-42.

[5] Oti, M. I. (1995). Design, manufacture and installation of multi-bladed wind mill. NJSE, 13, 110-117.

[6] Chegaar, M. and Chibani, A. (2000). A simple method for computing global solar radiation. Rev. Energ. Ren. Chem, 111-115. 
[7] Okogbue, E. C., Adedokun, J. A. and Holmgren, B. (2009). Hourly and daily clearness index and diffuse fraction at a tropical station, Ile-Ife, Nigeria. Int. J. Climatol. 29(8), 1035-1047.

[8] Udo, S. O. and Aro, T. O. (2000). New empirical relationships for determining global PAR from measurements of global solar radiation, infrared radiation or sunshine duration. Int. J. Climatol., 20, 1265-1274.

[9] Nwokolo, S.C. and Ogbulezie, J. C. (2017). A comprehensive review of empirical models for estimating global solar radiation in Africa. Renewable and Sustainable Energy Reviews, 78, 955-995. DOI: https://doi.org/10.1016/j.rser.2017.04.101

[10] Nigeria Meteorological Agency (NiMet) http://www.nimet.gov.ng/.

[11] Klein, S. A. (1977). Calculation of monthly average insolation on tilted surfaces. Solar Energy, 19(4), 325-329. DOI: https://doi.org/10.1016/0038092X(77)90001-9

[12] Amadi, S. O., Udo, S. O., and Ewona, I. O. (2014). The spatial and temporal variability of sunshine hours in Nigeria (1961-2012). IOSR J. Appl. Phys, 6(6), 110. DOI: 10.9790/4861-06630110

[13] Babatunde, E. B. (2001). Solar radiation modeling for a tropical station, llorin, Nigeria. Ph.D. Thesis

[14] Babatunde, E. B., and Aro, T. O. (2001). Characteristic variations of global (total) solar radiation at Ilorin, Nigeria. Nigeria Journal Solar Energy, 9, 157 - 173.

[15] Maduekwe, A. A. L., and Chendo, M. A. C. (1995). Predicting the components of the total hemispherical solar radiation from sunshine duration measurements in Lagos, Nigeria. Renewable Energy, 6(7), 807-812. DOI:

https://doi.org/10.1016/0960-1481(95)91008-2

[16] Fagbenle, R. O. (1993). Total solar radiation estimates in Nigeria using a maximum-likelihood quadratic fit. Renewable Energy, 3(6), 813-817. DOI: https://doi.org/10.1016/0960-1481(93)90089-Y

[17] Falayi, E., Adepitan, J., and Rabiu, A. (2008). Empirical models for the correlation of global solar radiation with meteorological data for Iseyin, Nigeria. International journal of physical sciences, 3(9), 210-216.

[18] Adaramola, M. S. (2012). Estimating global solar radiation using common meteorological data in Akure, Nigeria. Renewable Energy, 47, 38-44. DOI: https://doi.org/10.1016/j.renene.2012.04.005

[19] Ohunakin, O. S., Adaramola, M. S., Oyewola, O. M., and Fagbenle, R. O. (2013). Correlations for estimating solar radiation using sunshine hours and temperature measurement in Osogbo, Osun State, Nigeria. Frontiers in Energy, 7(2), 214-222. DOI: $10.1007 / \mathrm{s} 11708-013-0241-2$

[20] Okundamiya, M. S., Emagbetere, J. O., and Ogujor, E. A. (2016). Evaluation of various global solar radiation models for Nigeria. International Journal of Green Energy, 13(5), 505-512. DOI: 10.1080/15435075.2014.968921

[21] Ayodele, T. R., and Ogunjuyigbe, A. S. O. (2016). Performance assessment of empirical models for prediction of daily and monthly average global solar radiation: the case study of Ibadan, Nigeria. International Journal of Ambient Energy, 38(8), 803-813. DOI: 10.1080/01430750.2016.1222961

[22] Cornejo, L., Martín-Pomares, L., Alarcon, D., Blanco, J., and Polo, J. (2018). A through analysis of solar irradiation measurements in the region of Arica Parinacota, Chile. Renewable Energy, 112, 197-208. DOI: https://doi.org/10.1016/j.renene.2017.04.012 
[23] Polo, J., and Estalayo, G. (2015). Impact of atmospheric aerosol loads on Concentrating Solar Power production in arid-desert sites. Solar Energy, 115, 621-631. DOI: https://doi.org/10.1016/j.solener.2015.03.031

[24] Ramanathan, V., Crutzen, P. J., Kiehl, J. T. and Rosenfeld, D. (2001). Aerosols, climate and the hydrological cycle. Science, 294, 2119-2124.

[25] Spitters, C. J., and Musabilha, V. M. M. (1986). The Conservative Ratio of Photosynthetically Active to Total Radiation in the Tropics. Journal of Applied Ecology, 19(3), 853-858. DOI: 10.2307/2403287

[26] Black, J. N. (1954). The distribution of solar radiation over the Earth's surface. Archiv für Meteorologie, Geophysik und Bioklimatologie, Serie B, 7(2), 165-189. DOI: $10.1007 / \mathrm{BF} 02243320$

[27] Cartledge, O. (1973). Solar Radiation Climate in a Subtropical Region. Nature Physical Science, 242(114), 11-12. DOI: 10.1038/physci242011a0

[28] Iqbal, M. (1980). Prediction of hourly diffuse solar radiation from measured hourly global solar radiation on a horizontal surface. Solar Energy, 24(5), 491503.

[29] Tiba, C., and Fraidenraich, N. (2004). Analysis of monthly time series of solar radiation and sunshine hours in tropical climates. Renewable Energy, 29(7), 11471160. DOI: https://doi.org/10.1016/j.renene.2003.11.016

[30] Aguiar, R., and Boland, J. (1999). Interannual variability of meteorological parameters in temperate climates. In: 1999 ISES Solar World Congress, G. Grossman, ed., Elsevier, pp: I-353.

[31] Aguiar, R. J., Collares-Pereira, M., and Conde, J. P. (1988). Simple procedure for generating sequences of daily radiation values using a library of Markov transition matrices. Solar Energy, 40(3), 269-279. DOI: https://doi.org/10.1016/0038-092X(88)90049-7

[32] Graham, V. A., Hollands, K. G. T., and Unny, T. E. (1988). A time series model for Kt with application to global synthetic weather generation. Solar Energy, 40(2), 83-92. DOI: https://doi.org/10.1016/0038-092X(88)90075-8

Article copyright: (C) 2020 Solomon Okechukwu Amadi, Timothy Dike, Samuel Chukwujindu Nwokolo. This is an open access article distributed under the terms of the Creative Commons Attribution 4.0 International License, which permits unrestricted use and distribution provided the original author and source are credited. 